\title{
PENGARUH ROA, CAR, NPL, LDR, BOPO TERHADAP NILAI PERUSAHAAN BANK UMUM
}

\author{
Sundus Nur Halimah ${ }^{1)}$, Euis Komariah ${ }^{2)}$ \\ 1,2) Akademi Akuntansi Bina Insani \\ 1) sundusnurhalimah@gmail.com, ${ }^{2)}$ euiskh78@gmail.com
}

\begin{abstract}
This study aims to determine Effect of ROA, CAR, NPL, LDR, and BOPO partially and simultaneously on Firm Value. Samples were Commercial Bank Go Public is listed on the Indonesia Stock Exchange from 2011 to 2015 by using purposive sampling method. There are 25 Commercial Banks that qualify as research samples. The method of analysis in this research is multiple linear regression analysis. The results of this study show that ROA, CAR, and LDR significant effect on Firm Value, NPL and BOPO no significant effect on Firm Value. Simultaneously these variables significant effect on Firm Value.
\end{abstract}

Keywords: bopo, car, ldr, npl, firm value, roa.

\begin{abstract}
Abstrak
Penelitian ini bertujuan untuk mengetahui Pengaruh ROA, CAR, NPL, LDR, dan BOPO secara parsial dan simultan terhadap Nilai Perusahaan. Sampel penelitian ini adalah Bank Umum Go Public yang tercatat di Bursa Efek Indonesia dari 2011 hingga 2015 dengan menggunakan metode purposive sampling. Terdapat 25 Bank Umum yang memenuhi kriteria sebagai sampel penelitian. Metode analisis pada penelitian ini adalah analisis regresi linear berganda. Hasil penelitian ini menunjukkan bahwa ROA, CAR, dan LDR berpengaruh signifikan terhadap Nilai Perusahaan, sedangkan NPL dan BOPO tidak berpengaruh signifikan terhadap Nilai Perusahaan. Secara simultan variabel tersebut berpengaruh signifikan terhadap Nilai Perusahaan.
\end{abstract}

Kata Kunci: bopo, car, ldr, npl, nilai perusahaan, roa

\section{Pendahuluan}

Globalisasi yang terjadi saat ini telah merubah aspek ekonomi, politik serta budaya. Aspek ekonomi yang cepat tumbuh membuat modal yang diperlukan lebih banyak dalam meningkatkan perekonomian suatu negara. Kekuatan dari sistem perbankan adalah sebuah syarat esensial untuk menyakinkan kestabilan dan pertumbuhan ekonomi. Bagi pihak yang memiliki kelebihan dana, bank dapat digunakan sebagai tempat menyimpan dana dan meningkatkan jumlah dana mereka. Perusahaan dengan kinerja keuangan yang baik akan menghasilkan laba yang maksimal sehingga memiliki tingkat pengembalian investasi yang tinggi pada pemegang saham. Pengukuran nilai perusahaan dalam penelitian ini menggunakan Price to Book Value (PBV) sebagai variabel dependen karena PBV memiliki peran penting sebagai suatu pertimbangan bagi investor untuk memilih saham perusahaan yang akan dibeli.

Kinerja keuangan bank dapat dinilai dari rasio keuangan bank, seperti Return On Asset (ROA), Capital Adequacy Ratio (CAR), Non Performing Loan (NPL), Loan to Deposit Ratio (LDR), Biaya Operasional terhadap 
Pendapatan Operasional (BOPO). Beberapa hasil penelitian yang berbeda dari penelitianpenelitian terdahulu membuat penulis tertarik untuk melakukan penelitian pada bank umum go public yang dimulai dari tahun 2011-2015. Penelitian ini bertujuan untuk mengetahui pengaruh ROA, CAR, NPL, LDR, BOPO secara parsial (masingmasing) dan simultan (bersama-sama) terhadap Nilai Perusahaan pada Bank Umum Go Public tahun 2011-2015.

Sitepu (2015) menyatakan Nilai Perusahaan merupakan pengeluaran investasi yang memberikan sinyal positif dari investasi kepada manajer tentang pertumbuhan perusahaan di masa yang akan datang, sehingga meningkatkan harga saham sebagai indikator nilai perusahaan. Harga saham yang tinggi membuat nilai perusahaan juga tinggi. Nilai Perusahaan yang tinggi menjadi keinginan pemilik perusahaan, sebab dengan nilai perusahaan yang tinggi menunjukan kemakmuran pemegang saham juga tinggi.

Menurut Fahmi (2015) ROA adalah rasio yang digunakan untuk melihat sejauh mana investasi yang telah ditanamkan mampu memberikan pengembalian keuntungan sesuai dengan yang diharapkan. ROA yang positif menunjukkan bahwa dari total aktiva yang dipergunakan untuk beroperasi, perusahaan mampu memberikan laba bagi perusahaan. Sebaliknya apabila ROA yang negatif menunjukkan bahwa perusahaan mengalami kerugian. Bank Indonesia akan memberikan score maksimal 100 (sehat) apabila bank memiliki ROA > $1,5 \%$. Penelitian yang dilakukan oleh Hidayat (2014) dan Repi (2016) menunjukkan bahwa ROA berpengaruh positif signifikan terhadap Nilai Perusahaan. Berbeda dengan penelitian Anggitasari (2012) dan Putra (2007) menyatakan bahwa ROA tidak berpengaruh signifikan terhadap Nilai Perusahaan.

Fahmi (2015) Rasio kecukupan modal yang sering disebut dengan Capital Adequacy Ratio (CAR) mencerminkan kemampuan bank untuk menutup risiko kerugian dari aktivitas yang dilakukannya dan kemampuan bank dalam mendanai kegiatan operasionalnya. Sama halnya dengan perusahaan lain, bank memiliki modal yang dapat digunakan untuk kegiatan operasional bank. Modal bank terdiri dari dua macam yakni modal inti dan modal pelengkap. Sesuai peraturan Otoritas Jasa Keuangan permodalan minimum yang harus dimiliki bank adalah $8 \%$. Penelitian yang dilakukan oleh Hidayat (2014) menyatakan bahwa CAR berpengaruh positif tidak signifikan terhadap Nilai Perusahaan. Berbedaan dengan penelitian Srihayati (2015) yang memberikan hasil bahwa CAR tidak berpengaruh signifikan terhadap Nilai Perusahaan.

Kasmir (2015) NPL merupakan rasio yang dipergunakan untuk mengukur kemampuan bank dalam meng-cover risiko kegagalan pengembalian kredit oleh debitur. NPL mencerminkan risiko kredit, semakin kecil NPL semakin kecil pula risiko kredit yang ditanggung pihak bank. Rasio ini membandingan total kredit bermasalah termasuk kredit kurang lancar, diragukan dan macet terhadap total kredit. Ketentuan Bank Indonesia ialah bahwa bank harus menjaga NPL dibawah 5\%. Penelitian yang dilakukan oleh Srihayati (2015) dan Repi (2016) menyatakan bahwa NPL tidak berpengaruh signifikan terhadap Nilai Perusahaan, sedangkan dalam penelitian Hidayat (2014) memberikan hasil bahwa NPL berpengaruh negatif tidak signifikan terhadap Nilai Perusahaan.

Kasmir (2015) LDR adalah rasio yang digunakan untuk mengukur komposisi jumlah kredit yang diberikan dibandingkan dengan jumlah dana masyarakat dan modal sendiri yang digunakan. Apabila kredit yang disalurkan mengalami kegagalan atau bermasalah, bank akan mengalami kesulitan untuk mengembalikan dana yang dititipkan oleh masyarakat. Berdasarkan ketentuan Bank Indonesia, besarnya standar nilai Loan to Deposit 
Ratio (LDR) menurut Bank Indonesia adalah 92\%. Menurut penelitian Repi (2016) bahwa LDR berpengaruh signifikan terhadap Nilai Perusahaan, berbeda dengan penelitian Srihayati (2015) bahwa LDR tidak berpengaruh signifikan terhadap Nilai Perusahaan.

Dendawijaya (2009) Rasio biaya operasional digunakan untuk mengukur tingkat efisiensi dan kemampuan bank dalam melakukan kegiatan operasinya. Setiap peningkatan biaya operasional akan berakibat pada berkurangnya laba sebelum pajak yang pada akhirnya akan menurunkan laba atau profitabilitas bank. Bank Indonesia menetapkan angka terbaik untuk rasio BOPO adalah dibawah 90\%, karena jika rasio BOPO melebihi 90\% hingga mendekati angka 100\%, bank tersebut dapat dikategorikan tidak efisien dalam menjalankan operasinya. Penelitian yang dilakukan oleh Sumarningsih (2014) menunjukkan hasil BOPO berpengaruh signifikan terhadap Harga Saham, sedangkan menurut Srihayati (2015) BOPO tidak berpengaruh signifikan terhadap Nilai Perusahaan. Berdasarkan penjelasan teori dan hasil riset sebelumnya, maka dapat dikembangkan enam hipotesis sebagai berikut:

$\mathrm{H}_{1}$ : ROA berpengaruh signifikan terhadap Nilai Perusahaan.

$\mathrm{H}_{2}$ : CAR berpengaruh signifikan terhadap Nilai Perusahaan.

H3: NPL berpengaruh signifikan terhadap Nilai Perusahaan.

$\mathrm{H} 4$ : LDR berpengaruh signifikan terhadap Nilai Perusahaan.

H5: BOPO berpengaruh signifikan terhadap Nilai Perusahaan.

H6: ROA, CAR, NPL, LDR, dan BOPO secara simultan berpengaruh signifikan terhadap Nilai Perusahaan.

\section{Metode Penelitian}

Penelitian ini bersifat deskriptif kuantitatif dengan menggunakan data sekunder eksternal sebagai bahan penelitian. Data sekunder yang digunakan adalah berupa laporan keuangan bank umum periode 2011-
2015 yang terdaftar di Bursa Efek Indonesia. Dalam penelitian ini data tersebut meliputi ROA, CAR, NPL, LDR, dan BOPO sebagai variabel independen dan nilai perusahaan (PBV) sebagai variabel dependen. Metode pengambilan sampel dengan menggunakan metode purposive sampling, dengan jumlah sampel sebesar 25 perusahaan yang memenuhi kriteria dari 30 perusahaan. Sampel yang terpilih berdasarkan kriteria pemilihan dapat dilihat pada tabel 1 sebagai berikut:

Tabel 1.

Kriteria Sampel Penelitian

\begin{tabular}{|c|c|c|}
\hline No. & $\begin{array}{c}\text { Kriteria dengan } \\
\text { Purposive Sampling }\end{array}$ & Sampel \\
\hline & $\begin{array}{l}\text { 1.Bank Umum Go Public } \\
\text { yang tercatat di Bursa } \\
\text { Efek Indonesia (BEI) } \\
\text { pada tahun 2011-2015 }\end{array}$ & 30 \\
\hline 2. & $\begin{array}{ll}\text { Bank Umum } & \text { yang } \\
\text { memperoleh laba } & \text { dari } \\
\text { tahun } 2011-2015 . & \end{array}$ & 25 \\
\hline \multicolumn{2}{|c|}{ Total data (25 bank x 5 tahun) } & 125 \\
\hline
\end{tabular}

Sumber: Data diolah penulis

Return On Asset (ROA) adalah Rasio yang digunakan untuk mengukur kemampuan manajemen bank dalam memperoleh keuntungan atau laba keseluruhan. Capital Adequacy Ratio (CAR) adalah rasio kecukupan modal yang berfungsi menampung risiko kerugian yang kemungkinan dihadapi oleh bank. Non Performing Loan (NPL) merupakan rasio yang dipergunakan untuk mengukur kemampuan bank dalam meng-cover risiko kegagalan pengembalian kredit oleh debitur. Loan to Deposit Ratio (LDR) merupakan rasio untuk mengukur total kredit terhadap total dana pihak ketiga yang disalurkan dalam bentuk kredit.

Beban Operasional terhadap Pendapatan Operasional (BOPO) adalah rasio yang dipergunakan untuk mengetahui manajemen bank telah menggunakan semua faktor produksinya dengan efektif dan efisien. Teknik analisis data menggunakan analisis regresi linier berganda dengan program Statistical Package Social Sciences (SPSS) versi 23, sebelumnya data diuji terlebih dahulu dengan uji asumsi klasik yang terdiri 
dari uji normalitas, uji multikolinearitas, uji heteroskedastisitas, dan uji autokorelasi. Pengujian hipotesis dilakukan dengan menggunakan uji t, uji $\mathrm{F}$, dan uji koefisien determinasi.

\section{Hasil dan Pembahasan Analisis Deskriptif}

Penelitian ini dilakukan untuk menganalisis pengaruh Return On Asset (ROA), Capital Adequacy Ratio (CAR), Non Performing Loan (NPL), Loan to Deposit Ratio (LDR), dan Biaya Operasional terhadap Pendapatan Operasional (BOPO) terhadap Nilai Perusahaan (PBV) pada Bank Umum Go Public di Indonesia tahun 20112015. Berikut statistik deskriptif variabel penelitian yang dapat disajikan pada tabel 2 yaitu sebagai berikut:

Tabel 2.

\begin{tabular}{lcrrrr}
\multicolumn{5}{c}{ Hasil Uji Statistik Deskriptif } \\
\hline Descriptive Statistics \\
\hline Variabel & $\mathrm{N}$ & Minimum Maximum & Mean & $\begin{array}{c}\text { Std. } \\
\text { Deviation }\end{array}$ \\
\hline ROA & 125 & 0,06 & 4,56 & 1,9186 & 1,01900 \\
CAR & 125 & 10,25 & 27,91 & 16,6284 & 3,08237 \\
NPL & 125 & 0,21 & 4,74 & 2,0678 & 1,09004 \\
LDR & 125 & 44,24 & 140,72 & 83,6429 & 12,46507 \\
BOPO & 125 & 33,28 & 98,86 & 81,2405 & 10,33845 \\
PBV & 125 & 0,30 & 5,70 & 1,4957 & 0,96932 \\
\hline
\end{tabular}

Sumber: Data penelitian diolah dengan IBM SPSS 23

Tabel 2 yakni statistik deskriptif diperoleh berdasarkan data hasil dari olah data SPSS. Tabel tersebut menunjukkan bahwa variabel Return On Asset (ROA) dari 125 sampel penelitian diperoleh nilai rata-rata (mean) $1,9186>$ nilai standar deviasi 1,01900 sedangkan nilai tertinggi adalah 4,56 dan nilai terendah adalah 0,06. Capital Adequacy Ratio (CAR) dari 125 sampel penelitian diperoleh nilai rata-rata (mean) 16,6284 > nilai standar deviasi 3,08237 sedangkan nilai tertinggi adalah 27,91 dan nilai terendah adalah 10,25.

Non Performing Loan (NPL) dari 125 sampel penelitian diperoleh nilai rata-rata (mean) 2,0678> nilai standar deviasi 1,09004 sedangkan nilai tertinggi adalah 4,74 dan nilai terendah adalah 0,21. Loan to Deposit Ratio (LDR) dari 125 sampel penelitian diperoleh nilai rata-rata (mean) 83,6429 > nilai standar deviasi 12,46507 sedangkan nilai tertinggi adalah 140,72 dan nilai terendah adalah 44,24. Beban
Operasional terhadap Pendapatan Operasional (BOPO) dari 125 sampel penelitian diperoleh nilai rata-rata (mean) $81,2405>$ nilai standar deviasi 10,33845 sedangkan nilai tertinggi adalah 98,86 dan nilai terendah adalah 33,28. Price to Book Value (PBV) dari 125 sampel penelitian diperoleh nilai rata-rata (mean) 1,4957 > nilai standar deviasi 0,96932 sedangkan nilai tertinggi adalah 5,70 dan nilai terendah adalah 0,30. Nilai rata-rata (mean) ROA, CAR, NPL, LDR, BOPO, dan PBV lebih besar dari standar deviasinya yang menunjukkan penyebaran data yang baik.

\section{Uji Asumsi Klasik}

Uji asumsi klasik ini dilakukan agar memperoleh model regresi yang dapat dipertanggungjawabkan. Uji asumsi klasik dalam penelitian ini menggunakan uji normalitas, multikolinearitas, autokorelasi, dan heteroskedastisitas.

\section{Uji Normalitas}

Ghozali (2016) Pengujian ini dilakukan untuk menguji variabel independen dan dependen dalam model regresi memiliki distribusi normal atau tidak. Dalam penelitian ini uji normalitas yang dilakukan adalah analisis grafik dengan histogram dan normal probability plot (P-P Plot).

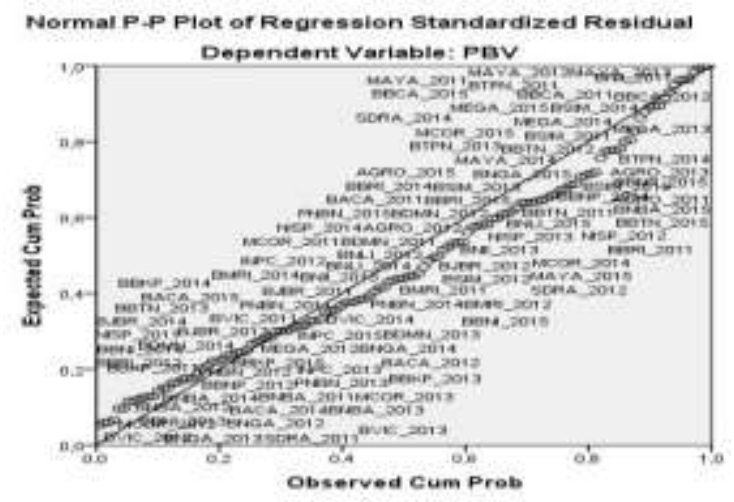

Gambar 1. Grafik Normal P-P Plot

17 | Jurnal Akuntansi, Ekonomi dan Manajemen Bisnis | Vol. 5 No. 1, July 2017, 14-25 | E-ISSN: 2548-9836 
Pada grafik diatas terlihat bahwa variabel berada menyebar berhimpit di sekitar diagonal dan mengikuti arah garis diagonal, hal ini menunjukkan bahwa residual terdistribusi secara normal.

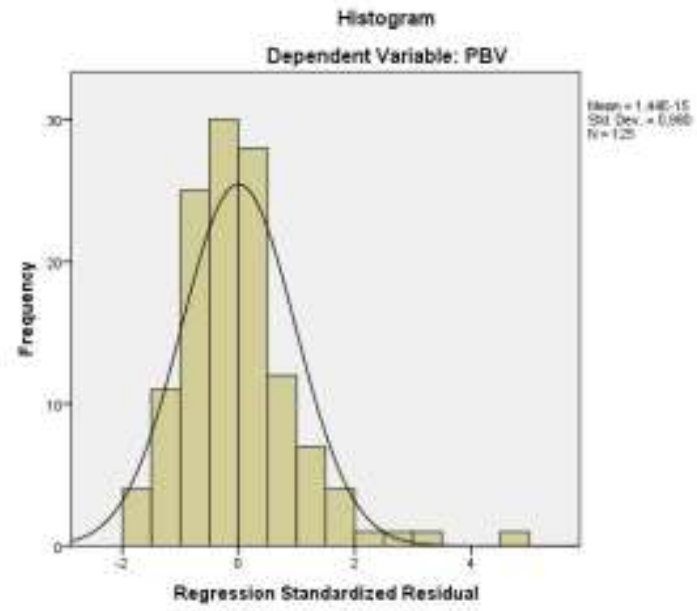

Gambar 2. Grafik Histogram

Hasil pengujian yang terlihat dari grafik histogram diatas menunjukkan grafik yang simetris, tidak melenceng ke kanan atau ke kiri yang artinya bahwa model regresi memiliki pola distribusi normal.

\section{Uji Multikolinearitas}

Ghozali (2016) untuk mengetahui Multikolinearitas dilihat dari nilai Tolerance dan Variance Inflation Factor (VIF), apabila nilai Tolerance $>0,10$ dan nilai VIF $<10$ berarti tidak terjadi multikolinearitas.

Tabel 3.

Hasil Uji Multikolinearitas

\begin{tabular}{cccc}
\hline \multicolumn{4}{c}{ Collinearity Statistics } \\
\hline Model & N & Tolerance & VIF \\
\hline 1 ROA & 125 & 0,282 & 3,552 \\
CAR & 125 & 0,909 & 1,100 \\
NPL & 125 & 0,792 & 1,263 \\
LDR & 125 & 0,850 & 1,177 \\
BOPO & 125 & 0,272 & 3,677 \\
\hline
\end{tabular}

Sumber: Data penelitian diolah dengan IBM SPSS 23 ROA memiliki nilai tolerance 0,282 > 0,10 dan nilai VIF 3,552 < 10. CAR memiliki nilai tolerance $0,909>0,10$ dan nilai VIF $1,100<$ 10. NPL memiliki nilai tolerance $0,792>$ 0,10 dan nilai VIF $1,263<10$. LDR memiliki nilai tolerance $0,850>0,10$ dan nilai $\mathrm{VIF}$ $1,177<10$.
BOPO memiliki nilai tolerance 0,272 > 0,10 dan nilai VIF $3,677<10$. Hal ini menunjukkan bahwa variabel ROA, CAR, NPL, LDR, BOPO tidak terjadi multikolinearitas.

\section{Uji Heteroskedastisitas}

Ghozali (2016) untuk mendeteksi adanya heteroskedastisitas dilakukan dengan melihat Grafik Scatterplot antara nilai prediksi variabel dependen yaitu ZPRED dengan residualnya SRESID, dimana sumbu Y adalah Y yang telah diprediksi dan sumbu $\mathrm{X}$ adalah residual ( $\mathrm{Y}$ prediksi dan $\mathrm{Y}$ sesungguhnya).

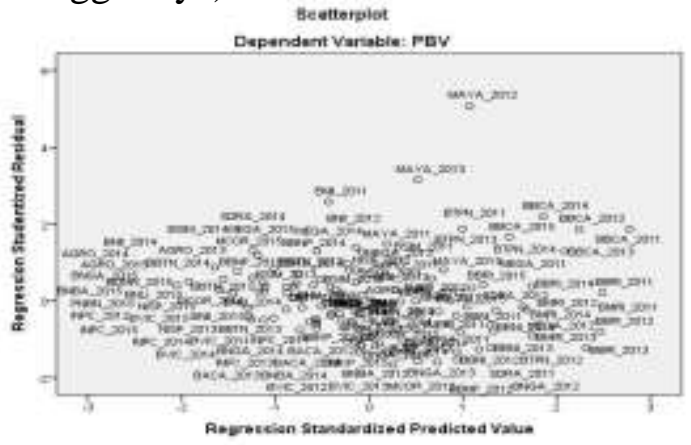

Gambar 3. Diagram Scatter Plot

Grafik diatas menunjukkan tidak adanya titik-titik yang membentuk pola tertentu secara teratur. Kesimpulan model regresi tidak terjadi heteroskedastisitas dan dikatakan memiliki hubungan yang baik.

\section{Uji Autokorelasi}

Ghozali (2016) dasar pengambilan keputusan dalam uji autokorelasi jika nilai Durbin-Watson (DW) antara 0-1,5 maka terjadi autokorelasi positif. Jika nilai DW antara 1,5-2,5 maka tidak terjadi autokorelasi. Jika nilai DW antara 2,5-4 maka terjadi autokorelasi negatif. Hasil uji autokorelasi dapat dilihat pada tabel 4 berikut ini:

Tabel 4.

Hasil Uji Autokorelasi Model Summary ${ }^{b}$

\begin{tabular}{cccccc}
\hline & & \multicolumn{3}{c}{ Adjusted R } \\
Model & $\mathrm{N}$ & $\mathrm{R}$ & $\mathrm{R}$ Square & Square & Durbin-Watson \\
\hline 1 & 125 & $0,706^{\mathrm{a}}$ & 0,498 & 0,477 & 2,191 \\
\hline
\end{tabular}

a. Dependent Variable: PBV

b. Predictors: (Constant), BOPO, CAR, LDR, NPL, ROA 
Sumber: Data penelitian diolah dengan IBM SPSS 23

Tabel hasil pengujian diatas menunjukkan bahwa nilai Durbin-Watson sebesar 2,191 yang berada diantara 1,5-2,5. Kesimpulan dari model regresi tidak terjadi autokorelasi.

\section{Analisis Regresi Berganda}

Regresi berganda dilakukan untuk mengetahui sejauh mana variabel bebas mempengaruhi variabel terikat. Model regresi berganda yang digunakan sebagai berikut:

\begin{tabular}{cccc}
$\gamma=\alpha+\beta_{1} X_{1}+\beta_{2} X_{2}+\beta_{3} X_{3}+\beta_{4} X_{4}+\beta_{5} X_{5}+e$ \\
Tabel 5. \\
\multicolumn{4}{c}{ Hasil Uji Regresi Berganda } \\
\hline \multicolumn{4}{c}{ Unstandardized Coefficients } \\
\hline N & $\mathrm{B}$ & Std. Error \\
\hline ROnstant) & 125 & 4,692 & 1,284 \\
CAR & 125 & 0,554 & 0,116 \\
NPL & 125 & $-0,101$ & 0,021 \\
LDR & 125 & 0,012 & 0,065 \\
BOPO & 125 & $-0,019$ & 0,005 \\
\hline
\end{tabular}

a . Dependent Variable: PBV

Sumber: Data penelitian diolah dengan IBM SPSS 23 Berdasarkan hasil tabel diatas dapat ditunjukkan persamaan analisis regresi linear berganda sebagai berikut:

$\gamma=4,692+0,554 \mathrm{x}_{1}-0,101 \mathrm{x}_{2}+0,012 \mathrm{x}_{\mathrm{1}}-0,019 \mathrm{x}_{4}-0,012 \mathrm{x}_{5}+\mathrm{e}$ Keterangan:

$$
\begin{array}{ll}
\gamma & =\text { Price to Book Value }(\mathrm{PBV}) \\
\alpha & =\text { Konstanta } \\
\beta_{1}-\beta \mathrm{s}=\text { Koefisien Regresi } & \\
& =\text { Return On Asset (ROA) } \\
& =\text { Capital Adequacy Ratio }(\mathrm{CAR}) \\
\mathrm{X} 1 & =\text { Non Performing Loan }(\mathrm{NPL})= \\
\mathrm{X} 2 & \text { Loan to Deposit Ratio }(\mathrm{LDR})= \\
\mathrm{X} 3 & \text { Biaya Operasional dan } \\
\mathrm{X} 4 & \text { Pendapatan Operasional (BOPO) } \\
\mathrm{X} 5 & \mathrm{e} \quad=\text { Error Term }
\end{array}
$$

Hasil persamaan regresi tersebut dapat dijelaskan sebagai berikut:

Nilai konstanta adalah sebesar 4,692, artinya apabila variabel independen meningkat satu satuan, maka Nilai Perusahaan (PBV) meningkat sebesar 4,692. Koefisien regresi X1 (ROA) bernilai positif sebesar 0,554 , artinya apabila X1 meningkat satu satuan, maka Nilai Perusahaan (PBV) akan meningkat sebesar 0,554, apabila variabel lainnya dianggap konstan. Koefisien regresi X2 (CAR) bernilai negatif sebesar $-0,101$, artinya apabila X2 meningkat satu satuan, maka Nilai Perusahaan (PBV) akan menurun sebesar $-0,101$, apabila variabel lainnya dianggap konstan.

Koefisien regresi X3 (NPL) bernilai positif sebesar 0,012, artinya apabila X3 meningkat satu satuan, maka Nilai Perusahaan (PBV) akan meningkat sebesar 0,012, apabila variabel lainnya dianggap konstan. Koefisien regresi X4 (LDR) bernilai negatif sebesar -0,019, artinya apabila X4 meningkat satu satuan, maka Nilai Perusahaan (PBV) akan menurun sebesar $-0,019$, apabila variabel lainnya dianggap konstan. Koefisien regresi X5 (BOPO) bernilai negatif sebesar -0,012, artinya apabila X5 meningkat satu satuan, maka Nilai Perusahaan (PBV) akan menurun sebesar 0,012 , apabila variabel lainnya dianggap konstan.

\section{Pengujian Hipotesis \\ Uji Statistik t (Uji Parsial)}

Uji statistik $\mathrm{t}$ digunakan untuk menguji secara parsial masing-masing variabel. Hasil uji t dapat dilihat pada tabel coefficients pada kolom sig (significance). Jika probabilitas nilai t atau signifikansi < 0,05, maka dapat dikatakan bahwa terdapat pengaruh signifikan antara variabel bebas terhadap variabel terikat secara parsial.

Tabel 6.

Uji Statistik t

\begin{tabular}{lrccc}
\hline Variabel & $\mathrm{N}$ & $\mathrm{t}$ & $\mathrm{Sig}$. & Hasil Penelitian \\
\hline ROA & 125 & 4,759 & 0,000 & Signifikan \\
CAR & 125 & $-4,717$ & 0,000 & Signifikan \\
NPL & 125 & 0,178 & 0,859 & Tidak signifikan \\
LDR & 125 & $-3,511$ & 0,001 & Signifikan \\
BOPO & 125 & $-1,049$ & 0,296 & Tidak signifikan \\
\hline
\end{tabular}

a . Dependent Variable: PBV

Sumber: Data penelitian diolah dengan IBM SPSS 23

Nilai $t_{t a b s l}$ dengan nilai signifikansi sebesar 0,05 berdasarkan uji 2 pihak (two tailed test) adalah sebesar 1,980. 
Berdasarkan tabel dan ketentuan di atas maka diambil keputusan:

$\mathrm{H}_{\mathrm{a}}$ : ROA berpengaruh signifikan terhadap Nilai Perusahaan. Hasil pengujian statistik t untuk variabel Return On Asset (ROA) menunjukkan $t_{\text {hitung }}$ sebesar 4,759 dengan nilai signifikansi $0,000<0,05$. Dapat disimpulkan bahwa variabel ROA mempunyai pengaruh signifikan terhadap Nilai Perusahaan yang artinya $\mathrm{H}_{0}$ ditolak dan $\mathrm{H}_{a}$ diterima.

Ha2: CAR berpengaruh signifikan terhadap Nilai Perusahaan. Hasil pengujian statistik t untuk variabel

Capital Adequacy Ratio (CAR) menunjukkan $t_{\text {hitung }}$ sebesar $-4,717$ dengan nilai signifikansi $0,000<0,05$. Dapat disimpulkan bahwa variabel CAR mempunyai pengaruh signifikan terhadap Nilai Perusahaan yang artinya $H o$ ditolak dan $H_{a}$ diterima.

$\mathrm{H}_{\mathrm{a} 3}$ : NPL berpengaruh signifikan terhadap Nilai Perusahaan. Hasil pengujian statistik t untuk variabel Non Performing Loan (NPL) menunjukkan $t_{\text {hitung }}$ sebesar 0,178 dengan nilai signifikansi $0,859>0,05$. Dapat disimpulkan bahwa variabel NPL tidak mempunyai pengaruh signifikan terhadap Nilai Perusahaan yang artinya $\mathrm{Ho}$ diterima dan $H a$ ditolak.

$\mathrm{H}_{\mathrm{a}}$ : LDR berpengaruh signifikan terhadap Nilai Perusahaan. Hasil pengujian statistik t untuk variabel Loan to Deposit Ratio (LDR) menunjukkan $t_{\text {hitung }}$ sebesar -3,511 dengan nilai signifikansi $0,001<0,05$. Dapat disimpulkan bahwa variabel LDR mempunyai pengaruh signifikan terhadap Nilai Perusahaan yang artinya $H o$ ditolak dan $H_{a}$ diterima.

Has: BOPO berpengaruh signifikan terhadap Nilai Perusahaan. Hasil pengujian statistik t untuk variabel Biaya Operasional Terhadap Pendapatan

Operasional (BOPO) menunjukkan

$t_{\text {hitung }}$ sebesar $-1,049$ dengan nilai signifikansi $0,296>0,05$. Dapat disimpulkan bahwa variabel BOPO tidak mempunyai pengaruh signifikan terhadap Nilai Perusahaan yang artinya $\mathrm{Ho}$ diterima dan $H_{a}$ ditolak.

\section{Uji Statistik F (Uji Simultan)}

Uji statistic $F$ digunakan untuk mengetahui kemampuan variable independen secara bersama-sama berpengaruh terhadap variabel dependen. Hasil dari Uji F tersebut dapat dilihat pada tabel 7 berikut:

Tabel 7.

Hasil Uji Statistik F ANOVA $^{\text {a }}$

\begin{tabular}{|c|c|c|c|c|c|}
\hline Model & $\begin{array}{l}\text { Sum of } \\
\text { Squares }\end{array}$ & df & $\begin{array}{l}\text { Mean } \\
\text { Square }\end{array}$ & $\mathrm{F}$ & Sig. \\
\hline 1 Regression & 58,046 & 5 & 11,609 & 23,631 & $0,000^{b}$ \\
\hline Residual & 58,462 & 119 & 0,491 & & \\
\hline Total & 116,508 & 124 & & & \\
\hline
\end{tabular}

a. Dependent Variable: PBV

b. Predictors: (Constant), BOPO, CAR, LDR, NPL, ROA

Sumber: Data penelitian diolah dengan IBM SPSS 23

Berdasarkan tabel dan ketentuan di atas maka diambil keputusan:

Ha6 : ROA, CAR, NPL, LDR, dan BOPO secara simultan berpengaruh signifikan terhadap Nilai Perusahaan. Hasil dari tabel diatas dapat dijelaskan bahwa nilai $F_{\text {tabol }}$ berdasarkan rumus df $=\mathrm{n}-\mathrm{k}-1$. Maka df = 125-5-1 = 119 dengan tingkat signifikansi 0,05 adalah sebesar 2,29. Nilai $F_{\text {hitung }}$ sebesar 23,631 dengan signifikansi $0,000<0,05$. Hasil pengujian menunjukkan bahwa variabel ROA, CAR, NPL, LDR, dan BOPO secara simultan berpengaruh signifikan terhadap Nilai Perusahaan (PBV) yang artinya $\mathrm{Ho}$ ditolak dan $H_{a}$ diterima.

\section{Koefisien Determinasi $\left({ }^{R^{2}}\right)$}

Koefisien Determinasi pada intinya mengukur seberapa jauh kemampuan model dalam menerangkan variabel dependen. Nilai koefisien determinasi antara nol dan satu. 
Tabel 8.

Uji Koefisien Determinasi

\begin{tabular}{cccccc}
\multicolumn{4}{c}{ Model Summary $^{\text {b }}$} \\
\hline Model & N & R & R Square & Adjusted R & \\
\hline 1 & 125 & $0,706^{\mathrm{a}}$ & 0,498 & 0,477 & Durbin-Watson \\
\hline
\end{tabular}

a. Dependent Variable: PBV

b. Predictors: (Constant), BOPO, CAR, LDR, NPL, ROA

Sumber: Data penelitian diolah dengan IBM SPSS 23

Berdasarkan tabel tersebut dijelaskan sebagai berikut: Nilai adjusted $\mathrm{R}$ sebesar 0,477 . Hal ini menunjukkan bahwa sebesar $47,7 \%$ variabel Nilai Perusahaan dijelaskan oleh ROA, CAR, NPL, LDR, dan BOPO, sedangkan 52,3\% variabel Nilai Perusahaan diprediksi dengan faktor-faktor lain selain ROA, CAR, NPL, LDR, dan BOPO.

\section{Kesimpulan, Implikasi, dan Keterbatasan}

\section{Kesimpulan}

Berdasarkan hasil analisis data dan pembahasannya yang telah dijelaskan di bab sebelumnya, maka kesimpulan dari penelitian ini adalah:

a. Hasil Pengujian Parsial (Uji Statistik t) ROA, CAR, dan LDR berpengaruh signifikan terhadap Nilai Perusahaan, sedangkan NPL dan BOPO tidak berpengaruh signifikan terhadap Nilai Perusahaan pada pada Bank Umum Go Public tahun 2011-2015.

b. Hasil Pengujian Simultan (Uji Statistik F)

$$
\text { ROA, CAR, NPL, LDR, dan BOPO }
$$$$
\text { secara simultan (bersama-sama) }
$$
berpengaruh signifikan terhadap Nilai Perusahaan pada Bank Umum Go Public tahun 2011-2015.

\section{Implikasi}

Berdasarkan hasil analisis data dan pembahasannya yang telah dijelaskan di bab sebelumnya, maka implikasi dari penelitian ini adalah:

a. Investor dalam berinvestasi atau menanamkan dana hendaknya memperhatikan pengaruh dari rasio ROA, CAR, NPL, LDR, dan BOPO terhadap Nilai Perusahaan yang diproksikan dengan PBV.

b. Nasabah dengan memperhatikan rasio seperti ROA, CAR, NPL, LDR, dan BOPO maka nasabah akan semakin memahami kemampuan Bank dalam mengelola dana.

c. Manajemen dengan memperhatikan pengaruh dari rasio ROA, CAR, NPL, LDR, dan BOPO terhadap Nilai

Perusahaan dalam pengambilan keputusan.

\section{Keterbatasan}

Penelitian ini masih mempunyai beberapa keterbatasan diantaranya hanya menggunakan 6 rasio karena adanya keterbatasan waktu. Dalam penelitian ini hanya menggunakan Bank Umum Go Public di Indonesia dengan tahun penelitian selama 5 tahun. Pemilihan sampel menggunakan purposive sampling yang menghasilkan 25 perusahaan Bank Umum Go Public dalam penelitian ini.

\section{Daftar Pustaka}

Anggitasari, N. \& Mutmainah, S. (2012).

Pengaruh kinerja keuangan terhadap nilai perusahaan dengan pengungkapan corporate social responsibility dan struktur good corporate governance sebagai variabel pemoderasi pada perusahaan manufaktur. Journal of Accounting, 1(2), 1-15.

Bank Indonesia. (2011). Surat edaran nomor 13/24/DPNP penilaian tingkat kesehatan bank umum di Indonesia.

Retrieved from http://www.bi.go.id/id/peraturan/perba nkan/Pages/SE\%20No.13_24_DPNP_ 2011.aspx

Bank Indonesia. (2011). Surat edaran nomor 13/30/DPNP tentang perubahan ketiga atas surat edaran nomor 3/30/DPNP tentang laporan keuangan 
publikasi triwulan dan bulanan bank umum. Retrieved from http://www.bi.go.id/id/peraturan/perba nkan/Pages/SE\%20No.13-30DPNP.aspx

Bank Indonesia. (2012). Peraturan Bank Indonesia nomor 14/14/PBI/2012 tentang transparansi dan publikasi laporan keuangan bank. Retrieved from

http://www.bi.go.id/id/peraturan/perba nkan/Pages/Peraturan_12102012.aspx

Bank Indonesia. (2013). Peraturan Bank Indonesia nomor 15/2/PBI/2013 tentang penetapan status dan tindak lanjut pengawasan bank umum

konvensional. Retrieved from http://www.bi.go.id/id/peraturan/perba nkan/Pages/PBI_15_2_PBI_2013.aspx

Bank Indonesia. (2015). Peraturan Bank Indonesia nomor 17/11/PBI/2015 tentang perubahan atas peraturan

Bank Indonesia nomor 15/15/PBI/2013 tentang giro wajib minimum bank umum dalam rupiah dan valuta asing bagi bank umum

konvensional. Retrieved from http://www.bi.go.id/id/peraturan/ssk/P ages/pbi_171115.aspx

Bank Indonesia. (2016). Laporan keuangan tahunan. Accessed on 25 Oktober 2016 from http://www.bi.go.id/id/publikasi/lapora n_keuangan/bank/umumkonvensional/Default.aspx

Brigham, E.F. \& Houston, J.F. (2010). Dasar-dasar manajemen keuangan (A. A. Yulianto, Trans.) (11 1 th ed.). Jakarta:

Salemba Empat.

Budisantoso, T. \& Nuritomo. (2014). Bank dan lembaga keuangan lain $\left(3^{\mathrm{rd}} \mathrm{ed}.\right)$. Jakarta: Salemba Empat.
Bursa Efek Indonesia. (2016). Laporan tahunan. Accessed on 24 Oktober 2016 from http://www.idx.co.id/idid/beranda/perusahaantercatat/laporan keuangandantahunan.aspx

Dendawijaya, L. (2009). Manajemen perbankan. Jakarta: Ghalia Indonesia.

Fahmi, I. (2015). Manajemen perbankan: Konvensional dan syariah. Jakarta: Mitra Wacana Media.

Ghozali, I. (2016). Aplikasi analisis multivariete dengan program IBM SPSS 23. Semarang: Badan Penerbit Universitas Diponegoro.

Gumanti, T.A. (2011). Manajemen investasi: Konsep, teori, dan aplikasi. Jakarta: Mitra Wacana Media.

Hanafi, M. \& Halim, A. (2012). Analisis laporan keuangan. Yogyakarta: UPP STIM YKPN.

Hermanto, B. \& Agung, M. (2015). Analisis laporan keuangan. Jakarta: Lentera Printing.

Hidayat, M. (2014). Pengaruh rasio kesehatan perbankan terhadap nilai perusahaan pada perbankan yang terdaftar di Bursa Efek Indonesia. Jurnal Ekonomi dan Informasi Akuntansi, 4(1), 41-47.

Kasmir. (2014). Analisis laporan keuangan. Jakarta: PT Raja Grafindo Persada.

Khaddafi, M. \& Syamni, G. (2011). Hubungan rasio camel dengan return saham pada perusahaan perbankan di Bursa Efek Indonesia. Jurnal Aplikasi Manajemen, 91(31), 910-918. 
Kurniadi, R. (2012). Pengaruh CAR, NIM,

LDR terhadap return saham pada perusahaan perbankan.

Accounting Analysis Journal, 1(1), 110.

Otoritas Jasa Keuangan. (2016). Otoritas Jasa Keuangan Republik Indonesia nomor 11/POJK.03/2016 tentang

kewajiban penyediaan modal minimum bank umum. Retrieved from http://www.ojk.go.id/id/kanal/perbank an/regulasi/peraturan-

ojk/Pages/pojk11-kewajiban-

penyediaan-modal-minimum-bank-

umum.aspx

Putra, T.P. \& Chabachib, M. (2007). Pengaruh kinerja keuangan dan beta saham terhadap price to book value pada perusahaan properti. Jurnal Studi Manajemen dan Organisasi, 4(2), 8190.

Repi, S. \& Murni, S. (2016). Faktor-faktor yang mempengaruhi nilai perusahaan subsektor perbankan pada BEI dalam menghadapi MEA. Jurnal EMBA, 4(1), 181-191.

Republik Indonesia. (1998). UndangUndang nomor 10 tahun 1998 atas perubahan Undang-Undang nomor 7 tahun 1992 tentang perbankan.

Retrieved from http://www.peraturan.go.id/uu/nomor10-tahun-1998.html

Sitepu, N.R. \& Wibisono, C.H. (2015). Pengaruh kebijakan dividen, kebijakan leverage, dan profitabilitas terhadap nilai perusahaan pada perusahaan manufaktur yang terdaftar di BEI pada tahun 2009-2013. Jurnal Bisnis dan Ekonomi, 27(1), 1-14.

Srihayati, D. \& Tandika, D. (2015). Pengaruh kinerja keuangan perbankan terhadap nilai perusahaan metode Tobin's Q pada perusahaan perbankan yang listing di Kompas 100. Seminar Penelitian Sivitas Akademika Unisba, 1, 43-49.

Sumarningsih, I.R. (2014). Pengaruh rasio indikator tingkat kesehatan bank terhadap harga saham perusahaan perbankan. Jurnal Ekonomi Pembangunan, 15(2), 1-17.

$\begin{array}{lrr}\text { Sunariyah. } & \text { (2011). } & \text { Pengantar } \\ \text { pengetahuan } & \text { pasar } & \text { modal. } \\ \text { Yogyakarta: } & \text { UPP STIM YKPN. }\end{array}$
Yogyakarta: UPP STIM YKPN. 


\section{LAMPIRAN}

Hasil Output Perhitungan Regresi Berganda dengan Program IBM SPSS 23

Model Summary ${ }^{\text {b }}$

\begin{tabular}{|l|r|r|r|r|}
\hline Model & $\mathrm{R}$ & R Square & $\begin{array}{c}\text { Adjusted R } \\
\text { Square }\end{array}$ & $\begin{array}{c}\text { Std. Error of the } \\
\text { Estimate }\end{array}$ \\
\hline 1 &, $706^{\mathrm{a}}$ &, 498 &, 477 &, 70091 \\
\hline
\end{tabular}

a. Predictors: (Constant), BOPO, CAR, LDR, NPL, ROA

b. Dependent Variable: PBV

Descriptive Statistics

\begin{tabular}{|l|r|r|r|r|r|}
\hline & N & Minimum & Maximum & Mean & \multicolumn{1}{c|}{$\begin{array}{c}\text { Std. } \\
\text { Deviation }\end{array}$} \\
\hline ROA & 125 &, 06 & 4,56 & 1,9186 & 1,01900 \\
CAR & 125 & 10,25 & 27,91 & 16,6284 & 3,08237 \\
NPL & 125 &, 21 & 4,74 & 2,0678 & 1,09004 \\
LDR & 125 & 44,24 & 140,72 & 83,6429 & 12,46507 \\
BOPO & 125 & 33,28 & 98,86 & 81,2405 & 10,33845 \\
PBV & 125 &, 30 & 5,70 & 1,4957 &, 96932 \\
Valid N (listwise) & 125 & & & & \\
\hline
\end{tabular}

Model Summary ${ }^{\text {b }}$

\begin{tabular}{|l|r|r|r|r|r|}
\hline Model & $\mathrm{R}$ & R Square & $\begin{array}{c}\text { Adjusted R } \\
\text { Square }\end{array}$ & $\begin{array}{c}\text { Std. Error of the } \\
\text { Estimate }\end{array}$ & Durbin-Watson \\
\hline 1 &, $706^{\mathrm{a}}$ &, 498 &, 477 &, 70091 & 2,191 \\
\hline
\end{tabular}

a. Predictors: (Constant), BOPO, CAR, LDR, NPL, ROA

b. Dependent Variable: PBV

\begin{tabular}{|c|c|c|c|c|c|c|}
\hline \multicolumn{7}{|c|}{ ANOVA“ } \\
\hline & & Sum of Squares & df & Mean Square & $\mathrm{F}$ & Sig. \\
\hline \multirow[t]{3}{*}{1} & Regression & 58,046 & 5 & \multirow{3}{*}{$\begin{array}{r}11,609 \\
, 491\end{array}$} & \multirow[t]{3}{*}{23,631} & \multirow[t]{3}{*}{, $000^{b}$} \\
\hline & Residual & 58,462 & 119 & & & \\
\hline & Total & 116,508 & 124 & & & \\
\hline
\end{tabular}

a. Dependent Variable: PBV

b. Predictors: (Constant), BOPO, CAR, LDR, NPL, ROA

\section{Coefficients $^{\mathrm{a}}$}

\begin{tabular}{|c|c|c|c|c|c|c|}
\hline \multirow{2}{*}{\multicolumn{2}{|c|}{ Model }} & \multicolumn{2}{|c|}{ Unstandardized Coefficients } & \multirow{2}{*}{$\begin{array}{c}\begin{array}{c}\text { Standardized } \\
\text { Coefficients }\end{array} \\
\text { Beta }\end{array}$} & \multirow[b]{2}{*}{$\mathrm{t}$} & \multirow[b]{2}{*}{ Sig. } \\
\hline & & $\mathrm{B}$ & Std. Error & & & \\
\hline \multirow[t]{6}{*}{1} & (Constant) & 4,692 & 1,284 & & 3,655 &, 000 \\
\hline & ROA &, 554 &, 116 &, 582 & 4,759 &, 000 \\
\hline & CAR &,- 101 &, 021 &,- 321 & $-4,717$ &, 000 \\
\hline & NPL &, 012 & ,065 & ,013 & ,178 & ,859 \\
\hline & LDR &,- 019 & ,005 &,- 247 & $-3,511$ &, 001 \\
\hline & BOPO &,- 012 & ,012 &,- 131 & $-1,049$ & ,296 \\
\hline
\end{tabular}

a. Dependent Variable: PBV 


\section{Coefficients $^{a}$}

\begin{tabular}{|c|c|c|c|c|c|c|c|c|}
\hline \multirow{2}{*}{\multicolumn{2}{|c|}{ Model }} & \multicolumn{2}{|c|}{$\begin{array}{c}\text { Unstandardized } \\
\text { Coefficients }\end{array}$} & \multirow{2}{*}{$\begin{array}{c}\text { Standardized } \\
\text { Coefficients } \\
\text { Beta } \\
\end{array}$} & \multirow[b]{2}{*}{$t$} & \multirow[b]{2}{*}{ Sig. } & \multicolumn{2}{|c|}{ Collinearity Statistics } \\
\hline & & B & Std. Error & & & & Tolerance & VIF \\
\hline 1 & (Constant) & 4,692 & 1,284 & & 3,655 &, 000 & & \\
\hline & ROA & ,554 & ,116 & ,582 & 4,759 & , 000 & 282 & 3,552 \\
\hline & CAR &,- 101 & ,021 &,- 321 & $-4,717$ & , 000 & ,909 & 1,100 \\
\hline & NPL & ,012 & ,065 & ,013 & ,178 & ,859 & ,792 & 1,263 \\
\hline & LDR &,- 019 & ,005 &,- 247 & $-3,511$ & ,001 & ,850 & 1,177 \\
\hline & BOPO &,- 012 & ,012 &,- 131 & $-1,049$ & ,296 & ,272 & 3,677 \\
\hline
\end{tabular}
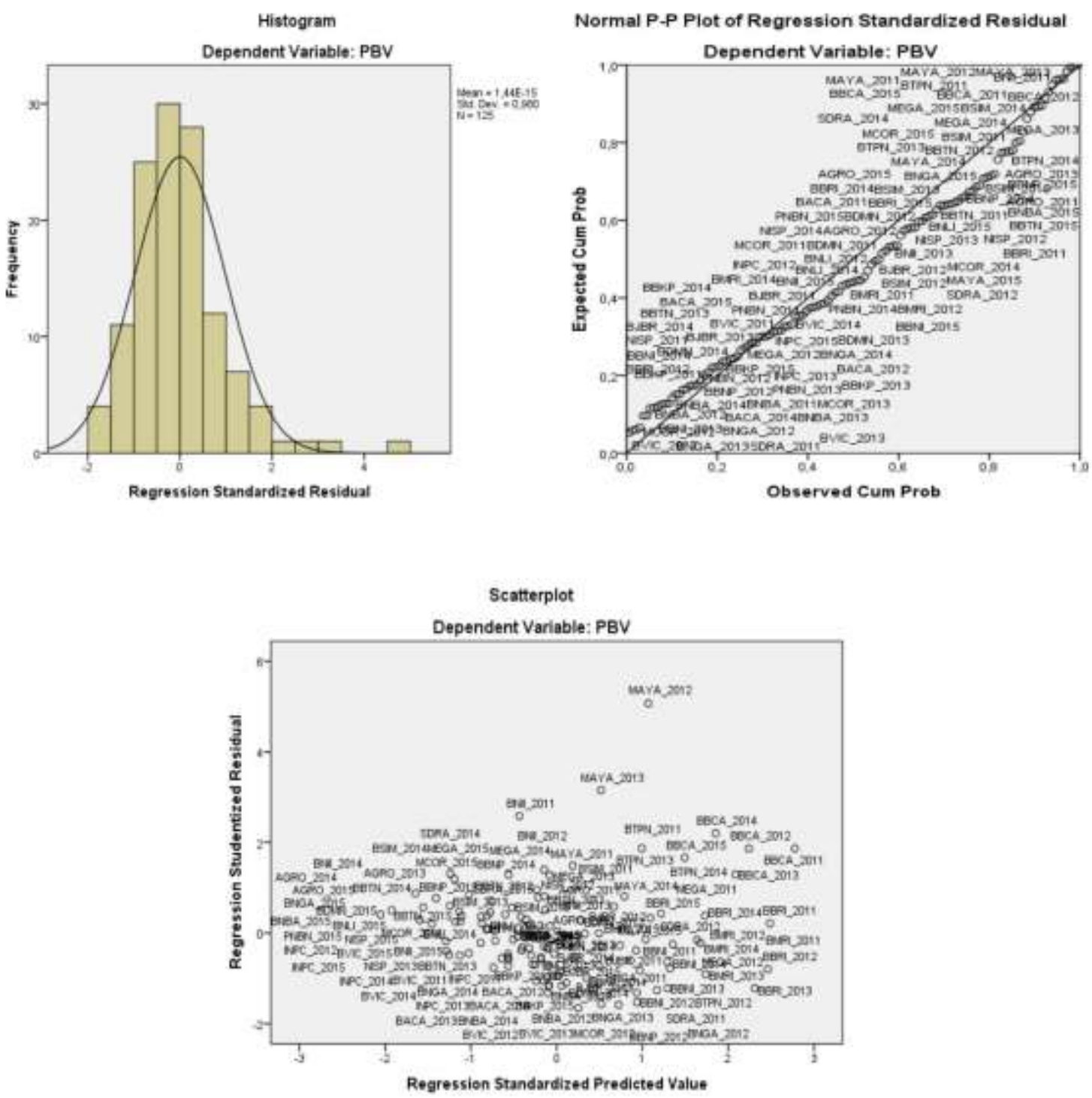